\title{
Paul McCartney and the creation of 'Yesterday': the systems model in operation
}

\author{
PHILLIP MCINTYRE
}

University of Newcastle, NSW 2308, Australia

E-mail: phillip.mcintyre@newcastle.edu.au

\begin{abstract}
By applying Mihaly Csikszentmihalyi's systems model of creativity, evidence can be presented to claim that despite 'Yesterday's promotion as a Romantic piece of creative activity, perpetuating the myth of the mystically inspired freely expressive artist, the creation of 'Yesterday' can be seen as a more considered and rational process than otherwise mythologised. The definition of creativity assumes an activity whereby products, processes and ideas are generated from antecedent conditions by the agency of someone, whose knowledge to do so comes from somewhere and the resultant novel variation is seen as a valued addition to the store of human knowledge. As an example of a system at work, the song's creation satisfies more closely the characteristics ascribed to the rationalist approach to creativity. From the evidence, it can be argued that creativity is a dynamic system that works on a larger scale than that of the sole individual posited by the Romantic conception and concomitant understandings. It, instead, incorporates the actions of the person, in this case Paul McCartney, within the systemic relationships of the field and domain. These three components, person, domain and field, comprise a system with circular causality where the individual, the social organisation they create within, and the symbol system they use are all equally important and interdependent in producing creative products. 'Yesterday' is but one creative product of this system at work.
\end{abstract}

In one short paragraph, Arthur Berger points out that 'artists tend to be the forgotten men and women in the field of mass communication scholarship' (Berger 1995, p. 145). He asserts that:

Researchers devote a great deal of attention to audiences and to the media, and to effects of mass-mediated texts on audiences in particular and on society in general. But there has not been a great deal of attention paid, generally speaking, to the people who write the scripts, perform them, direct the performers, and provide the technical expertise necessary to create texts of all kinds. (ibid, pp. 145-6)

With radio as one of the more ubiquitous forms of mass communication worldwide (Hendy 2000; Thussu 2002) - having, in the main, popular music as its chief source of content material - it would be pertinent to gain an understanding of how the producers of this particular content material, the artists we call songwriters and musicians, actually create their music. However, as Roy Shuker contends, knowledge about this area of creativity is sparse (Shuker 1994, p. 99) with some considered and detailed work only now beginning to appear (e.g. Toynbee 2000). In fact, one could go further, as Keith Negus and Michael Pickering have done, and suggest that: 
creativity is one of the most important yet unexplored issues in the study of popular music. Its significance is routinely noted, usually in passing, and its value often taken for granted. Its conceptual status in music studies is that of an unquestioned commonplace. Most of all, it is raised in reference to what is taken to be in opposition to it, to what is held as restricting or obstructing its realisation and potential ... What it involves in its own right or what meanings it is made to carry are seldom subject to any critical attention. (Negus \& Pickering 2002, p. 179)

With the study of mass communication as a domain of concern drawing on a number of interdisciplinary areas including, amongst others, sociology and psychology, it would also be apposite to heed the call of Mihaly Csikszentmihalyi. ${ }^{1} \mathrm{~A}$ psychologist himself, Csikszentmilahyi has argued for an amalgamation of sociological and psychological perspectives into a usable appraisal of the notion of creativity itself. In an early elucidation of the systems model of creativity he observed:

that some readers used to the person-centred perspective on creativity might begin to feel that the argument I am developing is a betrayal of psychology in favour of historical or sociological approaches. This is surely not my intention. It seems to me that an understanding of the complex context in which people operate must eventually enrich our understanding of who the individual is and what the individual does. But to do so we need to abandon the Ptolemaic view of creativity, in which the person is at the centre of everything, for a more Copernican model in which the person is part of a system of mutual influences and information. (Csikszentmihalyi 1988, p. 336)

Following the Aristotelian-aligned definition of creativity - most often utilised in one form or another throughout the last sixty to seventy years of study into creativity, particularly in the area of psychology (e.g. Stein 1953; Sternberg 1988, 1999; Bailin 1988; Csikszentmihalyi 1988; Weisberg 1993; Gardner 1993; Amabile and Tighe 1993; Boden 1994, 2004) - it can be claimed that creativity is an activity whereby products, processes and ideas are generated from antecedent conditions by the agency of someone, whose knowledge to do so comes from somewhere and the resultant novel variation is seen as a valued addition to the store of human knowledge.

In contrast, the Romantic view of creativity is most often seen as one where a creative person, operating under some form of mystical inspiration of mind or spirit, is not regulated by external phenomena but is an autonomous self who is expressive of their own free will. This person, in order to be 'truly' creative, must be liberated from constraints and allowed to operate as their muse suggests. This conception can be seen to be historically located (Williams 1961; Negus and Pickering 2004, pp. 7-9) but is often taken as transcendent truth (Petrie 1991). While this conception can't simply be reduced to the shibboleths of 'the muse' and 'divine inspiration', it can be claimed that it shares a certain set of characteristics with these latter conceptions such as a faith in the individual as a mystical harbinger of the creative act. As such it can also be grouped with the so-called 'genius' view, one bounded by 'the myth of monumental greatness' (Negus and Pickering 2004, p. 161), and thus possess the concomitant problems of that view (Stillinger 1991; Albert 1992; Weisberg 1993; Perelman 1994; Howe 1999). In addition to these contentions, as Wayne Weiten observes:

It is widely believed that creativity usually involves sudden flashes of insight and great leaps of imagination. Robert Weisberg (1986) calls this the 'aha! Myth'. Undeniably, creative bursts of insight do occur (Feldman 1988). However, the evidence suggests that major creative achievements are generally logical extensions of existing ideas, involving long, hard work and many small, faltering steps forward (Weisberg 1988, 1993). Creative ideas do not come out of nowhere. Creative ideas come from a deep well of experience and training in a specific area, whether it's music, painting, business, or science. As Snow (1986) puts it, 'Creativity is not a 
light bulb that is in the mind, as most cartoons depict it. It is an accomplishment born of intensive study, long reflection, persistence, and interest' (p. 1033). (Weiten 1998, p. 373)

Aligning more closely with this latter rationalist perspective is the systems model of creativity. The systems model sits inside what are referred to as confluence models of creativity (Sternberg 1999, pp. 10-12), themselves examples of the rationalist perspective. The model proposed by Csikszentmihalyi (1988, 1997, 1999), while re-conceptualising the creative act and de-centring the creative individual, does allow the space for acts of individual and extraordinary achievement to occur. However, these acts will occur within a framework of both enabling and constraining factors. As Bourdieu (1993), Giddens (1979), Boden (1994, 2004) and Archer (2003) have variously suggested, agents can never be absolutely free of structure and action may only occur as a result of these structures being in place. From this perspective, structures of the kind found in the customary practices, languages and symbol systems specific to popular music, as well as the socially organised world in which the individual operates - which includes industry functionaries, producers, engineers, media operatives and audiences - not only constrain but also enable the act of creativity to occur. As Margaret Boden argues:

... the ascription of creativity always involves tacit or explicit reference to some generative system. It follows too that constraints - far from being opposed to creativity - make creativity possible. To throw away all constraints would be to destroy the capacity for creative thinking. (Boden 1994, p. 79)

In line with these ideas and summarising the central ideas of the systems model, Csikszentmihalyi argues that:

... for creativity to occur, a set of rules and practices must be transmitted from the domain to the individual. The individual must then produce a novel variation in the content of the domain. The variation then must be selected by the field for inclusion in the domain. (Csikszentmihalyi 1999 , p. 315)

It is the prime contention of this paper that the creation of the popular song 'Yesterday' accords more closely with this systems model, as an example of the rationalist perspective, than it does with the mystically inclined Romantic perspective with which the writing of this song is most often associated (e.g. Salewicz 1986; Snow 1995). With this contention in mind it would be apposite to look in detail at this specific incidence of creativity in action and see whether the systems model is demonstrable in this particular case. ${ }^{2}$ This may be demonstrated by looking at Paul McCartney ${ }^{3}$ as an agent who acts within the constraining and enabling factors of the system and ascertaining whether he had access to the domain of knowledge of song-writing and what interaction occurred with the field, that is, the social organisation that understands and makes decisions about the domain. As such, McCartney may be conceived, in Negus and Pickering's terms, as an exceptional creator who 'cannot be isolated from the ordinariness of human life' (Negus and Pickering 2004, p. 160); one who is fundamentally located within 'changing biographical circumstances, social relationships, economic imperatives, stylistic conventions and historical traditions' (ibid., p. 161). As Cook and Mercer also argue, 'songwriters are people working inside cultures and social contexts' (in Inglis 2000, p. 87). These views also accord in some ways with Heinonen and Eerola's (2000) assertion that a songwriter's aesthetic ambitions are bounded by professional pressures and personal experiences.

Bearing in mind that if creativity is conceptualised as systemic, and thus a holistic and integrated activity between person, domain and field, we could attempt to 
tease out these complexities by, firstly, investigating McCartney's access to the domain and his relationship as an agent, both constrained and enabled by this process, with that domain. Secondly, we would need to identify the relationship to the field McCartney had access to and what that field contributed to the decisions being made about the song 'Yesterday'.

To begin that exercise of seeing what connection McCartney had, firstly, with the domain of popular songs, we would need to start at the point the song is believed to have been first manifest. Ray Coleman, in his in-depth study of 'Yesterday' (Coleman 1995), writes that in November 1963 Paul McCartney woke late, as was his usual practice, in the upstairs bedroom of the Asher family's residence in Wimpole St, London. He had been dreaming of a melody which was still running around his brain. He sleepily moved to the piano that was close to his bed and played. His first thought was that this tune was one of the standards such as 'Stairway to Paradise', 'Chicago', 'Lullaby of the Leaves', or one similar, that his father had played. Growing up in a tight-knit and gregarious working-class, Irish/Scottish, Catholic/Protestant, Liverpudlian family whose pivotal event was the Second World War, provided Paul McCartney with a wealth of songs to add to his musical memory. From this community, McCartney had open access to the currently popular songs of the day via a number of sources including the songs his relatives played both in the family sing-along format and on record. His father was also, after-hours, an amateur dance band leader and musician. McCartney thus engaged with a host of standards, singalong tunes and light classical pieces familiar to this cross-generational set of relatives and friends, as well as the flood of material bought into England by both the 18,000 American troops stationed close by to Liverpool at RAF Burtonwood, and the many sailors who plied the Atlantic merchant seaman's run from America and back to Liverpool.

The list of songs he and the other Beatles had contact with, apart from the early rock and rollers' songs, includes the country sounds of Hank Williams, Slim Whitman and Buck Owens; theme songs from shows and films; piano pieces from Fats Waller; the easy listening repertoire of singers like Vera Lynn, Dinah Washington, Frankie Lane and Nat King Cole; the Blues and R\&B of The Isley Brothers, Bobby Parker, Ray Charles, Arthur Alexander and Joe Turner; as well as jazz standards such as 'Sweet Georgia Brown', 'Somewhere Over the Rainbow', 'Falling in Love Again', 'September in the Rain', 'Begin the Beguine' and a host of songs written by Cole Porter, Hoagy Carmichael, Jerome Kern, George and Ira Gershwin, Irving Berlin and many others (Pedler 2001A; Lewisohn 1992; Coleman 1995; Martin 1994).

Ian Hammond (2002) has argued that 'Yesterday's antecedents can be traced to a single source within this tradition. In support of his argument, Hammond contends that McCartney was familiar with and admired the work of Ray Charles. It's Charles' version of Hoagy Carmichael's 'Georgia on My Mind' that, as Hammond argues, provides the starting point for McCartney's 'Yesterday'. ${ }^{4}$ While Hammond asserts that 'Yesterday' was not just a derivation but a 'stunning composition in its own right' and a 'completely original and individual' tune (Hammond 2002), he outlines the similarity, not the exact match, in melodic content (with 'Yesterday's melody allegedly following the bass part of the original tune), the similar theme and most importantly for Hammond, the equivalent chord progressions. ${ }^{5}$ He argues that Hoagy Carmichael's original composition had been significantly transformed by Louis Armstrong's version and Ray Charles took this process a few steps further by never singing 'Georgia' the same way twice. 'Yesterday', as Hammond's central 
premise asserts, was another step in that process of transformation or recomposition where all songs can be seen as being antecedently linked in one form or another to other pre-existing songs, ${ }^{6}$ a proposition that tends to support the hypothesis that domain acquisition is a necessary part of the creative process. In support of this idea Hammond states that he doesn't ' know where Hoagy Carmichael got his inspiration from, but I'd be pretty certain we'd find it part of a song tradition stretching back hundreds of years' (Hammond 2002). Access to this lengthy song tradition through the wealth of material he had come into contact with, including in this case 'Georgia on My Mind ${ }^{7}$ thus also afforded McCartney a deep immersion in the domain of the popular music of the day.

While Heinonen (cited in Heuger 2005) has argued that this immersion process is pre-compositional, a stage which encompasses an enculturation into the knowledge of song-writing, it can also be argued that immersion in the domain, according to Csikszentmihalyi, is a prerequisite for creativity in any domain and is thus more fully characterised as part of the creative act. Csikszentmihalyi asserts that the information that feeds into the idea was in existence prior to the individual's actions and use of it. This information was 'stored in the symbol system of the culture, in the customary practices, the languages the specific notation of the domain' (Csikszentmihalyi 1988, pp. 325-39).

It is the task of the person working within the creative process to produce some variation in this inherited information, conventions, rules and ideas. Weisberg contends that it is difficult to find a person 'who has made a significant contribution to a creative discipline without first having deep initial immersion in that discipline' (Weisberg 1999, p. 242). For McCartney, this process of immersion and its usefulness in the creative exercise held true throughout his career. A close friend, Barry Miles, observed of McCartney that 'anything musical that he learns goes immediately into his head and is liable to resurface years later, when for whatever reason he knows that he needs it' (quoted in Salewicz 1986, p. 174). This view accords with Cook and Mercer's assertion that a songwriter's work is bound to 'reflect their conscious and unconscious responses to the lives they are living' (in Inglis 2000, p. 87). It's not surprising then for McCartney to assume that the melody he dreamed was simply one of the songs he remembers hearing in his formative years:

I first thought: oh, it must be one of those old songs . . I've just forgotten which one. But I had this piano by the bed ... I just fell out of bed, found out what key I had dreamed it in, and it seemed near G, and I played it. I said to myself: I wonder what it is, you know. I just couldn't figure it out at all, because I'd just woken up. And I got a couple of chords to it. I got the G, then I got the nice F sharp minor seventh, that was the big waaaahhhh. That led very naturally to the $\mathrm{B}$ which led very naturally to the E minor. It just sort of kept tumbling out with those chords. I thought: well this is very nice, but it's a nick, it's a nick [from another song]. I don't know what it is ... We were always very careful . . the great danger with writing is that you write someone else's song without realising. You spend three hours . . . and you've written a Bob Dylan classic. This one, I was convinced, was just something I'd heard before. I said to people: well, it can't be mine, I just woke up dreaming [italicised in original] it! There was no logic to it at all. And I'd never had that. And I've never had it since. This was the crazy thing about this song. It was fairly mystical when I think about it, because of the circumstances. It was the only song I ever dreamed. (McCartney quoted in Coleman 1995, pp. 6-7)

The fact that McCartney dreamed the song, suggesting a mystical occurrence, has become lore within circles of Beatles' aficionados. For example, Chris Salewicz writes that 'Yesterday':

... was one of the easiest pieces of writing Paul had ever done. Falling out of bed one morning, he went straight to the piano (on which he had started taking formal lessons) and - still close to 
his unconscious dream state - played as the song flowed from him with an ease that suggested divine inspiration. 'It was one of the most instinctive songs I've ever written', he said later. (Salewicz 1986, pp. 171-2)

Even McCartney has speculated on the origins of the tune stating that:

'Yesterday' came out of the blue, I've no idea where from. I dreamed the melody. I woke up and I had the melody in my head. It depends how far you want to go with this; if you're very spiritual then God sent me a melody, I'm a mere vehicle. If you wanna be a bit more cynical, then I was loading my computer for millions of years listening to all the stuff I listened to through my dad and through my musical tastes, including people like Fred Astaire, Gershwin, and finally my computer printed out one morning what it thought was a good tune. (McCartney quoted by Snow 1995, p. 57)

It is the latter option, it is contended, that can be seen as the more demonstrable of the two. Barry Miles, for one, hypothesises that an explanation for this occurrence can be found in the Freudian idea that:

... dream formation is determined in part by the previous day's activities and it would be interesting to know what Paul had been listening to the night before. The melody of 'Yesterday' may be a dream-work transformation of something completely unlikely, from a television theme song to a classical piece; or, more probably, a musical idea he had already been playing with but which emerged from the dream state so different that it was unrecognisable. The notes had to be there already in his subconscious, but Paul's musical vocabulary had become so vast, his subconscious so saturated with chord progressions, note combinations and fragments of melody, that in this instance he did not have to even place himself in a receptive songwriting mode; he just put them together in a new way while he was asleep. (Miles 1997, p. 203)

This sounds a plausible hypothesis. It should be remembered, however, that Freud's ideas have come under considerable reconsideration recently, predominantly over his exploration of dream interpretation (Watson 2001). Nonetheless, it has been argued (Wolman 1979) that Freud's theory of dream formation was a conceptually different project to that of his ideas on dream interpretation. In fact, this aspect of his thinking on dream formation may have prefigured some later thinking in cognitive psychology. In terms of the way dreams are formed, Freud indicated his belief that, in part, 'residues of the previous day have been left over from the activity of waking life and it had not been possible to withdraw the whole cathexis of energy from them' (Jones in Wolman 1979, p. 276). Cavallero and Foulkes also argue that there are some things of value in Freud's ideas on dream formation which:

looks surprisingly cognitive in the contemporary sense. Here Freud is not so much concerned with specific content (why or how did I come to dream/think that particular thing?) As with generalised processes (how are dreams generated by the mind?) ... Freud's dream process psychology foreshadowed the paradigm later adopted by cognitive psychology: compare inputs with outputs and then model the transformations that might underlie the intervening mental processing'. (Cavallero and Foulkes 1993, p. 5)

Rosalind Cartwright also believes that there is 'considerable continuity between waking and sleeping thought' (Weiten 1998, p. 197), while George Mandler argues that some themes of dreams 'may be activated by events of the preceding day, or they may be activated simply because a reasonable number of their features have been left over as residues from the day before' (Mandler 1995, p. 14).

While the proponents of these ideas deal in differing areas of investigation about dreaming, there is, according to the above, certainly agreement that prior experience will supply data for dream content. These positions then tend to partially support the activation-synthesis hypothesis proposed by McCarley and Hobson who assert, according to Sternberg, that: 
... dreaming represents a person's subjective awareness and interpretation of neural activity during sleep ... our acceptance of bizarre occurrences in dreams is caused by changes in brain physiology. That is, just as our brains also organise sensory information during wakefulness, our brains also organise sensory information during sleep. (Sternberg 1995, p. 210)

While these ideas are largely conjectural, and they have as yet to be adequately tested, they do present a more feasible set of explanations of this dream occurrence than that proposed by the 'genius'-inclined models of creativity, where the muse or a form of divine inspiration provides the mystical breakthrough, often in dreams or dreamlike states, necessary for creativity to occur. For example, it is not unreasonable to assume that, in addition to the store of songs resting in his memory as a result of the immersion process, as outlined above, McCartney's activities in the days prior to 'dreaming' the melody were filled with the musical concerns of a busy professional musician. In short, and to put this colloquially, it can be demonstrated he was living and breathing music.

During the month of November 1963, the period in which he dreamt the melody (Coleman 1995), McCartney was performing songs night after night and also conducting music-related activity during the day, with the exception of one unaccountedfor day. In this month he was engaged with the Beatles in their 1963 Autumn Tour of Britain. The set list, without variation in this period, consisted of the songs: 'I Saw Her Standing There', 'From Me To You', 'All My Loving', 'You Really Got A Hold On Me', 'Roll Over Beethoven', 'Boys', 'Till There Was You', 'She Loves You', 'Money (That's What I Want)' and 'Twist and Shout' (Lewisohn 1992, p. 127). Sixty-four per cent of these songs were written by composers other than Lennon and McCartney. The itinerary for this period (Schultheiss 1980, pp. 64-8; Lewisohn 1992, pp. 127-30) had the group giving a performance every evening. They were not only playing songs but they were also talking and thinking about music as their itinerary was interspersed with a significant number of television and radio appearances and interviews during the day. 7 November through to 9 November also saw Alun Owen join them on tour to observe their activity, taking these observations and then translating them into the script for the Beatles' film, A Hard Day's Night. On the same day that President J.F. Kennedy was assassinated, 22 November, the Beatles released their second album, With the Beatles, which reached No. 1 on 30 November. 11 November is the only day unaccounted for during this busy musical period.

These engagements were part of a continuing and escalating number of performances that for the composers had begun in 1957. As Robert Weisberg notes, 'beginning in mid-1960, they were performing approximately 400 times per year - on average more than once per day' (Weisberg 1999, p. 239). Out of an eventual repertoire of 250 songs for the period between 1957 and 1963, most of those performed during this period, in fact over ninety per cent, were of songs written by other composers (Weisberg 1999, p. 239). In addition, George Harrison has declared that the Beatles' period of toiling for hours a day on stage in their early days in Hamburg were directly formative. He explains that the band was forced to play a wide variety of material to fill the eight-hour sets they were engaged to play. 'Suddenly, we were even playing movie themes, like 'A Taste of Honey' and 'Moonglow', learning new chords, jazz voicings, the whole bit. We learned a lot from doing that. Eventually, it all combined together to make something new and we found our voice as a band' (Harrison, quoted in Pedler 2001B, p. 33). Weisberg asserts that this intense immersion in the domain of song-writing was important for both Lennon and McCartney in order for them to 'learn their craft' (Weisberg 1999, p. 240). Weisberg argues that: 
... deep immersion provides extensive opportunities for practising any skills, such as playing the piano, required to create within the domain, which makes them automatic. Automaticity of skills may be necessary for the production of novelty, for example, improvisation of new melodies. (Weisberg 1999, p. 247)

This preceding point is similar to that of Donald Schon's notions proposed in The Reflective Practitioner: How Professionals Think in Action (1983). Schon asserts in this book that practitioners utilise what he calls 'reflection-in-action'. He argues that the spontaneous behaviour of skilful practice is, according to Chester Barnard, a form of non-logical process 'which are not capable of being expressed in words or as reasoning, and which are only made known by a judgement, decision or action' (Schon 1983, p. 51). Schon argues, via Barnard, that our bias towards logical analytical thinking 'blinds us to the non-logical processes which are omnipresent in effective practice' (ibid., p. 52). He also draws on Michael Polanyi's notion of 'tacit knowing'. This process, Schon argues, is essential to the acquisition of a skill, and the feelings we acquire in repetitive exercise of the practice, which we are firstly aware of, become 'internalised in our tacit knowing' (ibid., p. 52). Schon argues that 'we are often unaware of having learned to do these things; we simply find ourselves doing them' (ibid., p. 52). These ideas tend to support the notion of intuition as global processing suggested by Tony Bastick, who contends that intuition is a form of non-linear parallel processing of global multi-categorised information as opposed to its traditional understanding as a mystical or metaphysical process (Bastick 1982, p. 215).

These ideas also correspond in some ways to the propositions put forward by Pierre Bourdieu $(1977,1993)$. Bourdieu has argued that, in order for a person to become a cultural producer utilising the knowledge base, the internalised codes and manner of thought of the maker, that person must firstly acquire the cultural capital pertinent to their area of concern. In acquiring this knowledge they undergo a long process of inculcation or immersion in the knowledge, developing a 'feel' for it, or a sense of how it operates. Bourdieu calls this feel for the way things are done 'habitus'. Bourdieu argued that the components of habitus are not produced idiosyncratically but are actually produced in the wider society and the agents within that society choose from within these limits:

The habitus is the product of the work of inculcation and appropriation necessary in order for those products of collective history, the objective structures (e.g. language, economy, etc.) to succeed in reproducing themselves more or less completely, in the form of durable dispositions. (Bourdieu 1977, p. 85)

It is a person's habitus that inclines, or predisposes, them to act and react in particular ways in particular situations. He argues that this ability to engage in a cultural practice circumscribes a cultural producer's choices while at the same giving them the ability to make those choices.

In précis, McCartney's life-long immersion in the domain, his acquisition of the songwriter's habitus and his daily activity during the period he 'dreamed' the verse melody of 'Yesterday', may account for the idea that his mind was input with comparatively constant musical sounds and ideas, with the resultant global processing occurring during his sleep and outputting as a specific melodic fragment. He then made the choice to keep and work on this melodic fragment, acting wholly within the parameters of his songwriter's knowledge or domain. Weisberg further argues that:

a large amount of domain specific practice is necessary [italics in original] for the development of the skills that underlie creative accomplishment, not that practice is sufficient for creative accomplishment. Production of masterworks requires not only a large amount of practice, but 
also the coming together of a number of different sorts of external factors, many of which are independent of the amount of study and practice put in by a given individual. (Weisberg 1999, pp. 241-2)

These factors independent of the individual include the role of professional decisionmakers and the audience in what, for Csikszentmihalyi, constitutes the field. It is to a consideration of the role the field plays in the system of creativity, and McCartney's relationship to it, that we should now turn.

Csikszentmihalyi asserts that 'what we call creativity is a phenomenon that is constructed through an interaction between producer and audience [italics in original]' (Csikszentmihalyi 1999, p.314). From this position Csikszentmihalyi argues that creativity cannot be seen as 'the product of single individuals, but of social systems making judgements about individual's products' (ibid.). Therefore, for Csikszentmihalyi, 'the easiest way to define a field is to say that it includes all those who can affect the structure of a domain' (Csikszentmihalyi 1988, p. 330). 'Field' in this sense is similar to Becker's use of the term 'art world' (Becker 1982) and also corresponds in some ways to Bourdieu's notion of 'field' where it is seen as an arena of contestation $^{8}$ (Bourdieu 1993). It is related to the social organisation of the world the person operates in. A field 'is necessary to determine whether the innovation is worth making a fuss about' (Csikszentmihalyi 1997, p. 41). Csikszentmihalyi asserts that fields can affect creativity in a number of ways. Some of these include, firstly, being reactive or proactive. A reactive field, according to this thesis, does not solicit novelty whereas a proactive one does by actively demanding novelty from the artists concerned. In this way the social organisation that governs popular music, for example, requires constant novelty in order to maintain its commercial base. Secondly, the field can affect creativity by choosing a broad or narrow filter in the selection of novelty. As Csikszentmihalyi asserts:

Some fields are conservative and allow only a few new items to enter the domain at any given time. They reject most novelty and select only what they consider best. Others are more liberal in allowing new ideas into their domains, and as a result these change more rapidly. (Csikszentmihalyi 1997, p. 44)

Part of the operation of the dynamic field of popular music in allowing new variations into the domain is to provide verification that the creative activity has made an original contribution to the domain. Csikszentmihalyi asserts that attributions of creativity must always be relative and must be grounded in social agreement. From this position it follows that 'social agreement is one of the constitutive aspects of creativity, without which the phenomenon would not exist' (Csikszentmihalyi 1988, p. 326). From this perspective, acts of creativity are thus only creative within a specific sociocultural framework. This idea is at the heart of one of the central debates in studies on creativity. The arguments surrounding the debate can be traced, in part, to the idea of consensual validation in pre-adolescence first suggested by Harry Stack Sullivan during the 1940s (Sullivan 1955, p. 43). Using these ideas as a springboard, Morris Stein published an article entitled 'Creativity and Culture' in The Journal of Psychology (1953) in which he worked his way through a definition of creativity that was phrased as follows: 'the creative work is a novel work that is accepted as tenable or useful or satisfying by a group in some point in time' (Stein 1953, p. 311). His general argument suggests that if the only criteria to judge whether a person, product or process was creative or not was that an amalgamation of past experiences or products to produce something new was revealed, then any idea or product, no 
matter how absurd or bizarre, would qualify as being creative. As many theorists since have contended (Gardner 1993; Boden 1994; Csikszentmihalyi 1997), as did Stein, this latter way of looking at creativity provides no reasonable access to what makes the creative product distinctive in relation to other ideas, products or objects. It is only in the process of social validation that a process, product or idea can be seen as being creative. As Csikszentmihalyi contends, it is not possible to 'introduce a variation without reference to existing patterns. "New" is only meaningful in reference to the "old". Original thought does not exist in a vacuum' (Csikszentmihalyi 1999, pp. 314-15).

During the northern winter of 1963-1964, with McCartney being at the epicentre of the field for the popular music industry of the time in Britain, he had little trouble finding members of the field familiar enough with the domain to verify the melody he was working on as being unique and valuable. As McCartney has stated 'first of all I checked the melody out, and people said to me, "No it's lovely, and I'm sure it's yours" ... It had no words' (Miles 1997, p. 202). He played it to quite a number of people in the process of verifying the tune as original. As Coleman (1995) indicates, he played the melody to his writing partner John Lennon who could not recognise the melody and consequently indicated he thought it was an original tune. McCartney also played it for Lionel Bart, another well-known composer who could neither read nor write sheet music but had composed hit songs and musicals. Bart when hummed the melody, also did not recognise it and told McCartney he should pursue it. As Coleman reiterates, late one evening in Autumn 1963 McCartney also took the melody to Alma Cogan's home. Cogan was a well-known singer who also had developed a coterie of show-business types who regularly attended parties at her home. Lennon and McCartney often mingled with other well-known celebrities at these parties. McCartney informed Cogan that he had a new tune:

I played the melody for her and she said 'It's lovely'. It was a little bit embarrassing because I think she thought I'd written it for her. Maybe I didn't make it very clear by saying: here's a song I've written; what do you think of it? I probably said: 'this is something I've written; does this remind you of anything?'. (McCartney quoted in Coleman 1995, p. 9)

As a working songwriter, McCartney was also adept at taking happenstance circumstances and working them into ideas for his songs. Coleman goes on to write that Alma's sister, Sandra, remembers their mother, Fay, walking into the room as McCartney was playing the melody on the piano, asked the three of them, 'Anyone like some scrambled eggs?', prompting McCartney to begin singing 'Scrambled eggs ... Oh my baby how I love your legs . . oh . . scrambled eggs' (Coleman 1995, p. 9). ${ }^{9}$ These scratch lyrics stayed wedded to the tune for some time. McCartney's former teacher 'Dusty' Durband remembers a visit from McCartney during this period when he played the piece on the household piano, singing the 'scrambled egg' working lyric (Salewicz 1986, p. 172). The use of the scratch lyric has been confirmed many times (Gambaccini 1976; Smith in De Lisle 1995; Snow 1995; Miles 1997). McCartney next remembers working on the piano in his bedroom in Wimpole Street:

... putting the middle in, what we used to call middle-eights, even if they were middle-sixteen bars or middle-thirty-twos. They were always, to us, middle-eights, because we had heard some musicians call that part of a song the middle-eight. (quoted in Coleman 1995, p. 10)

It has also been noted that he worked on the middle-eight, the B section of the ternary song form, during the filming of the Help movie (Miles 1997, p. 203). ${ }^{10}$ His preoccupation with the song on the set drove the director Dick Lester to distraction 
who demanded that he finish it or give it up (Coleman 1995, p. 16). McCartney began the task of doing just that.

While he now had compiled a complete tune, verse and middle-eight, McCartney was still stuck singing the scratch lyrics suggested to him by Fay Cogan's question. He has since said that:

... the only difficult thing was the words originally blocked out were, 'Scrambled eggs/Oh my baby/How I love your legs'. So I knew that had to change. I had to get something that scanned like 'scrambled egg' - 'tomorrow night' - no that doesn't scan ... 'morning light?' And all of them were crap. And then 'yesterday' - wow. And that just sat, and then 'suddenly', and once I had those two words it came. (McCartney quoted by Snow 1995, p. 57)

The lyrics were the product of some considerable work. On 27 May 1965, after the completion of the Help film location shoot, McCartney flew to the southern coast of Portugal for a holiday at his friend Bruce Welsh's house in Albufeira in the Algarve. Welsh was the rhythm guitarist and songwriter for the Shadows. Jane Asher accompanied him. ${ }^{11}$ When they landed they were then driven along the 180 -mile road route to the house. McCartney took the opportunity to think through the song that had plagued him since November 1963:

It was a long hot, dusty drive. Jane was sleeping but I couldn't, and when I'm sitting that long in a car I either manage to get to sleep or my brain starts going. I remember mulling over the tune 'Yesterday', and suddenly getting these little one-word openings to the verse. I started to develop the idea: Scram-ble-d eggs, da-da da. I knew the syllables had to match the melody, obviously: da-da da, yes-ter-day, sud-den-ly, fun-il-ly, mer-il-ly, and yes-ter-day, that's good. All my troubles seemed so far away. It's easy to rhyme those 'a's: say, nay, today, away, play, stay, there's lots of rhymes and those fall in quite easily, so I gradually pieced it together from that journey. Sud-den-ly, and ' $\mathrm{e}$ ' again, another easy rhyme: e, me, tree, flea, we, and I had the basis of it. (quoted in Miles 1997, p. 204)

Once he arrived at Welsh's villa he asked for a guitar as Bruce Welsh was leaving and immediately commenced work on completing the lyrics:

I think I finished the lyrics about two weeks later. Which was quite a long time for me. Generally, John and I would sit down and finish within three hours, but this was more organic. I put in the words over the next couple of weeks. (quoted in Miles 1997, p. 205)

From this point McCartney continued his practice of performing what he had for those members of the field who would listen. When he arrived at the recording sessions for the Help album he played it for the other members of the team, as was their usual practice. As John Lennon, McCartney's song-writing partner attested in 1974:

... even with ones where we'd have it 90\% finished, there's always something added in the studio. A song is - even now when I write a song - not complete. I can never give my song to a publisher before I've recorded it, however complete the lyrics and the tune and the arrangement are on paper, because it changes in the studio'. (Lennon quoted in The Beatles 2000, p. 98)

Heinonen has noted that the cultural production process of the Beatles, split between two distinct stages of song-writing and recording, typically involved a series of events that may overlap and be non-sequential in as much as the writers returned to certain stages while proceeding through each one (in Heinonen and Eerola 2000). These ideas correspond in some senses to Wallas's notions of creativity as a process ${ }^{12}$ that can be best described in terms of stages that are, according to later formulations, iterative and 'less linear than they are recursive' (Csikszentmihalyi 1997, pp. 80-1). This differentiation by Heinonen between song-writing and recording, as two distinct phases of the process, though certainly traditional in conception, ${ }^{13}$ raises the question of 'what' is actually being created here? As Jon Fitzgerald writes: 
...various authors (e.g. Hesbacher 1973, p. 297; Hennion 1983, p. 163; Moore 1993, p. 32) have stressed the importance of considering the sound recording as musical text ... Hennion (1983, p. 161) goes so far as to say that 'the song is nothing before the arrangement' - arguing that creation 'occurs at the moment of orchestration, recording, and sound mixing'. (Fitzgerald 1996, pp. 20-1)

Despite these differing assumptions of what constitutes a song, and at what point it comes into being, the author has argued elsewhere that the domain of songs, and thus the activities and tasks of songwriters, now includes not only lyric and melody writing but also a manipulation of:

... simple and complex harmonic and rhythmic features such as accompaniment, arrangement or orchestration, and according to some perspectives, [this manipulation] would also include performance characteristics and production elements. (McIntyre 2001, p. 109)

As members of the field aware of these aspects of the domain of song-writing, both George Harrison's and John Lennon's reaction to McCartney's presentation of his material in the recording studio was that they thought it was good but they could contribute nothing to it. Ringo didn't think drums would add to it either. George Martin, their producer, who had heard the tune in its embryonic form in the Hotel George V in Paris, ${ }^{14}$ told McCartney the title wasn't particularly original as there was already a standard called 'Yesterdays' recorded by Peggy Lee (Coleman 1995; Miles 1997). ${ }^{15}$ Both apparently were unaware of the previous existence of a song already titled 'Yesterday' written by Charles Harrison and Monte Wilhite and published by the Ted Brown Music Co. from Chicago in $1926 .{ }^{16}$ On McCartney's insistence the title 'Yesterday' remained. Much more to McCartney's horror, however, Martin suggested the use of strings in its arrangement (Martin 1979, pp. 166-7). 'Are you kidding [italics in original]? The Beatles is a rock' $n$ 'roll group!' exclaimed McCartney (quoted in Coleman 1995, p. 43). Once Martin clarified that he was interested in a string quartet and that it would be in the nature of an experiment, McCartney organised to sit down with Martin and worked out the arrangement for the strings. He went 'round to George's house and we had a pleasant couple of hours, had a cup of tea, sat there with the manuscript paper on the piano' (quoted in Miles 1997, p. 206):

So George showed me this voicing, and I said 'lovely' and we did the whole song, very straight, for a string quartet. And there was just one point in it where I said, 'Could the cello now play a slightly bluesy thing, out of the genre, out of keeping with the rest of the voicing?' George said, 'Bach certainly wouldn't have done that, Paul, ha ha ha'. I said 'Great!' That was what we often used to do, try and claim our one little moment. I mean, obviously it was my song, my chords, my everything really, but because the voicing now had become Bach's, I needed something of mine to redress the balance. So I put a 7th in, which was unheard-of. It's what we used to call a blue note, and that became a little bit well known. It's one of the unusual things in that arrangement. (quoted in Miles 1997, p. 206)

McCartney also put forward the idea of the first [upper] violin holding the high note in the final section. Martin quietly acknowledged the adventurousness of McCartney in suggesting the innovative use of the blues note in this arrangement (Lewisohn 1988, p. 59), remembering that this use of a minor against a major was Paul's idea, 'and I wish it had been me. John Lennon fell in love with that particular sound when he first heard it' (Coleman 1995, p. 46). As Margaret Boden (1994, p. 76) points out, it is this particular combination - strings within a pop format - that justifies in many people's minds the creative contribution the song made to what then constituted the domain of popular music. 
One more innovation that has been little commented on seems to have occurred as far as the arrangement goes. One that the Beatles would have taken for granted given their approach to the guitar. While the use of a capo is well known amongst guitarists as a device to alter keys without changing the essential tonality of the piece - one used repeatedly by the Beatles - the particular method of changing key and tonality used on the recording is not fully recognised. Since McCartney originally worked out his 'dream' melody in the key of $G$ on the piano he may have found this key was generally unsuitable for his voice for this particular song. But since he transferred the song in this key to the guitar he might also have felt the tonality of this key on the guitar was apt for the recording of the song. The recorded work, however, is in the key of F (relative to concert pitch), but McCartney refers to it always in reference to the key of G. For guitarists, the key of F not only proves more difficult to play but has less of a ringing and open quality than the key of $G$, a quality that would have no doubt appealed to McCartney's finely tuned musical sensibilities. What appears to have happened is that:

... he sings it in the key of F, but he actually plays it on the guitar in G, so the acoustic guitar has been dropped a tone. He probably did this because the open string sound of the $G$ chord was a better sound, but he wanted his vocal to be in F. So he dropped the acoustic guitar a tone so that he could play G, but he was actually forming a G chord. (Cooper quoted in Coleman 1995, p. 83)

This observation can be verified as it is commensurate with the televisual image of McCartney playing the song solo and using open position chords in the key of G during the Beatles' appearance on The Ed Sullivan Show. This show was broadcast on the CBS television network in the US on 9 September 1965. The appearance was pre-taped on 14 August and during rehearsals on this day McCartney performed an amusing version of the song singing its original scratch lyrics and accompanying himself on Hammond organ (Fulpen 1983, p. 93). ${ }^{17}$

However, it was the tonality of the guitar version in $\mathrm{G}$ that featured in the earlier version recorded for the studio album Help. Without the benefit of his years of guitar playing and composition on the instrument, that is, the benefit of his understanding of this domain, McCartney would not have realised the possibilities the guitar offered. As Jason Toynbee has argued (Toynbee 2000, p. 38), relying on Bourdiu's notion of 'possibles', a musician will identify and select musical possibilities from within a radius of possible choices, not limitless choices, that intersect with the musician's habitus plus the rules of the field they operate in. Conversely some ideas are unlikely to be selected because they are too far from the centre of the musician's habitus. This understanding of what was possible, for Bourdieu an entwining of agency and structure, ${ }^{18}$ must have been in place for McCartney as he transferred the song from piano to guitar, well before he arrived at EMI's Abbey Road recording studio for work in Studio 2.

After spending the early part of Monday 14 June 1965 in the studio recording 'I've Just Seen a Face' and the rock'n'roll shouter 'I'm Down', McCartney then proceeded during the evening, in a three and a half hour session beginning at 7.00 p.m. (Lewisohn 1988, p. 59), to record his guitar and vocal part onto a four-track tape with the second take marked 'best' (Coleman 1995, p. 42). Three days later the strings were overdubbed. However, McCartney was once again perturbed by the strings. He quickly asked Martin what the shaking sound was the string players were producing and was informed that they were using vibrato. McCartney, wary of the effect this would have on the song, suggested that 'it sounded a little too gypsy-like 
for me' (quoted in Coleman 1995, p. 43). He asked producer George Martin whether the violinist could perform without their normal use of vibrato and Martin asked what the problem was with this technique:

McCartney answered that it reminded him of Mantovani's lush strings, of the Victor Sylvester Orchestra which he'd heard on the radio as a child and which used that effect from the violin. Wide though his interests were in music, there was a line, never to be crossed, between rich, fine music and over-the-top cornball. Vibrato represented that to him. (Coleman 1995, p. 43)

Martin then asked first violinist Tony Gilbert if the string players could stop using this technique. Complying with the wishes of their employer, the musicians proceeded to play the parts as requested with McCartney pleased with the results. He observed that:

When they dropped the vibrato, it sounded stronger. Before it had sounded quite classical enough. Now it was no longer like the old gypsy violinist playing around a campfire! It was ... on the money! (quoted in Coleman 1995, p. 45)

First violinist with the Duke String Quartet, Louise Fuller, who performed this particular arrangement during the 1990s, commented that:

... if the strings were taken away from the song, it might not be such a powerful performance. The strings don't come in until the second verse and when they do, it's a really beautiful moment. People who listen to the words won't think of that. When he sings 'Suddenly, I'm not half the man I used to be', the strings subconsciously move people more than they realise [Also] if you take vibrato away you have to work much, much harder with your bow to get the Beatles sound ... In a string quartet, where you have four people playing close harmony, as on 'Yesterday', if you are not using vibrato, the musicians have to hit every note accurately. On the top note of the McCartney record, vibrato is apparent. I don't know if it crept in and Paul McCartney wished it hadn't, but it does sound nice. (Fuller quoted in Coleman 1995, p. 84)

However, there was one extra, almost imperceptible and certainly serendipitous element that became part of the final recording. An 'additional vocal track' (Lewisohn 1992, p. 196) was recorded on the same day the strings were overdubbed ${ }^{19}$ on Thursday 17 June. As George Martin notes:

Because we didn't use headphones there was leakage from the studio speaker into his microphone, giving the impression of two voices or double-tracking. (Martin quoted in Lewisohn 1988, p. 59)

Finally, on Thursday 17 June 1965, after fifteen months, the song as it has become known to the world was fully recorded. 'Complete now in its stunning simplicity, the song was mixed into mono' (Lewisohn 1992, p. 196).

While the central intent of this paper has not been to tackle a definitive descriptive analysis of the song (if such a thing was possible) but examine the way it came into being, it does however seem to be reasonable at this concluding point to provide, as a summary, a brief descriptive account of the completed work. ${ }^{20}$ As a fully realised song, 'Yesterday' was, and is, structurally a classic ternary (AABA) form piece, a form typical of the pre-war popular style and favoured, as Jon Fitzgerald asserts, by John Lennon and Paul McCartney (in Inglis 2000, p. 71) during their early period. ${ }^{21}$ Lyrically it can be seen to be a song that deals with nostalgia for a lost love or, dependent on audience interpretation, a concomitant recognition of one's own maturation in the face of lost innocence. Describing the song as 'a small miracle', Wilfrid Mellers asserts that its 'immediate nostalgia' is reinforced by the 'music's frail bewilderment' (Mellers 1973, p. 57). Melodically it stays mainly in the key of F. It ventures periodically outside the diatonic F major scale as the harmonic progression 
pivots around this tonal centre, although the first fixed version of it is played on guitar tuned a tone below concert pitch. This method uses the tonalities and resonances of the guitar as they are produced in the key of $G$ played in first position a full step down. The song also utilised a string quartet for simple yet effective accompaniment capturing the essence of the feeling, as Mellers argues, without dipping into 'cornball' by staying, at the moment one expects the strings to indulgently soar, on 'a long inverted pedal thereby inducing a wide-eyed wonder, with a tinge of apprehension' (Mellers 1973, p. 57). Since its creation, 'Yesterday' has been valued by a large audience and proven to be enduringly popular. It has been played on US radio 6,480,000 times, averages 50,000 plays on American radio every three months and has become one of the world's most recorded songs (Coleman 1995, pp. 162-3). ${ }^{22}$

In conclusion, given the evidence presented above, the writing of 'Yesterday' was certainly not an overnight item falling complete from the dream consciousness of Paul McCartney. It was instead the result of a long and often arduous but nonetheless highly explainable process springing from McCartney's deep well of experience, his intensive immersion in the domain of popular songs, and the product of long reflection and persistence. It's verification as creative owes a considerable debt to the members of the field McCartney had access to, with its meaning constructed and reconstructed through its many interactions with audience members, also seen as critical components of the popular music field. Despite the song's promotion as a Romantic piece of creative activity, perpetuating the myth of the mystically inspired freely expressive artist, the creation of 'Yesterday' can be seen, in analysis, as a more considered and rational process than otherwise mythologised. Following the definition of creativity being used here, that is, that creativity is an activity whereby products, processes and ideas are generated from antecedent conditions by the agency of someone whose knowledge to do so comes from somewhere and the resultant novel variation is seen as a valued addition to the store of human knowledge, the production of 'Yesterday', occurring within the interactive system of domain, field and person, can be seen as a creative act. As an example of a system at work, the song's creation satisfies more closely the characteristics ascribed to the rationalist approach to creativity. Indeed, from the evidence, it can be argued that creativity is a dynamic system that works on a larger scale than that of the sole individual posited by the Romantic conception and concomitant understandings, and instead incorporates the actions of the person within the systemic relationships of the field and domain. These three components, person, domain and field, comprise a system with circular causality where the individual, the social organisation they create within, and the symbol system they use are all equally important and interdependent in producing creative products. 'Yesterday' is but one creative product of this system at work.

\section{Endnotes}

1. Mihaly Csikszentmihalyi is pronounced phonetically as 'Me-high Chick-sent-me-high-ee'.

2. There are certain methodological concerns associated with the problems of 'single song' approaches. It could be argued that many more examples would be needed to strengthen the theory's applicability in the case of musical creation generally. This is the fundamental problem with a case study approach and attempting to generalise out of single cases. However, this is a methodological concern common to any case study approach and, as Robert K. Yin has argued, 'case studies, like the experiment, do not represent a "sample", and the investigator's goal is to expand and generalise theories (analytic generalisation) and not to enumerate frequencies (statistical generalisation)' (Yin 1989, p. 21). 
3. While the song is credited to Lennon/ McCartney, it has been generally agreed that this song was instigated by Paul McCartney (see, for example, Elson 1986; Lewisohn 1992; MacDonald 1994; Coleman 1995; Beatles 2000).

4. McCartney himself has noted that the use of other songs as templates is not unusual. For example, he states that 'in my mind "Hey Jude" is a nick from the Drifters. It doesn't sound like them or anything, but I know that the verse, with those two chords repeating over and over, came when I was fooling around playing "Save the Last Dance for $\mathrm{Me}^{\prime}$ on the guitar" (McCartney, quoted in Gelly 1976, p. 47).

5. A word of caution needs to be placed here as the proliferation of this type of chord progression can be heard throughout many Tin Pan Alley standards, themselves sourced from a diverse array of what became generic styles peculiar to the early twentieth century. It may be that the generic style rather than the actual song was the source.

6. Without making a case for memetics, it's interesting to note the links that can be made between evolving cultural products or forms and the use of a computer program like EVOLUTION as outlined in Chapter 3, 'Accumulating Small Change', in Richard Dawkins' book The Blind Watchmaker (1986). Figures 4 through to 7 in this chapter give, for this author, a visual analogue of the ideas Ian Hammond is describing in his own work.

7. A reference to Carmichael's tune can be heard in the bridge section (referred to by the composers as the middle eight) of the later Beatles' song, 'Back in the USSR'.

8. It should be noted that Bourdieu has written elsewhere that 'without entering into a methodological expose of everything that separates this vision of the 'world of art' from the theory of the literary or artistic field, I will merely remark that the latter is not reducible to a population [italics in original], that is to say, to the sum of individual agents linked by simple relations of interaction, or more precisely, of cooperation: what is lacking, among other things, from this purely descriptive and enumerative evocation are the objective relations which are constitutive of the structure of the field and which orient the struggles aiming to conserve or transform it' (Bourdieu 1996, p. 205).

9. McCartney has been quoted in other sources as saying: 'The tune came just like that, although I didn't have words for it. It was breakfast time so I sang, 'Scrambled egg, How I love to eat a scrambled egg ...' until, several days later, I fitted 'Yesterday' to the first three notes and I was away' (quoted in Gelly 1976, p. 45). This may well be the case, especially if one sees the Cogan anecdote as another example of McCartney playing around with the possibilities of the unfinished song. However, he has also been quoted elsewhere as stating that the original words blocked out were indeed
'Scrambled eggs/ Oh my baby/ How I love your legs' (Snow 1995, p. 57).

10. Both of these sources, Coleman (1995) and Miles (1997), have McCartney's imprimatur.

11. It has been suggested that McCartney's relationship to both Jane Asher and his deceased mother have been motivating factors in his songwriting. Heinonen (Heuger 2005), Elson (1986) and Coleman (1995) have variously suggested songs such as 'Yesterday' were musical manifestations of a personal mourning process for the songwriter who worked out his relationships to these two significant women in his life through his songs.

12. In 1926, Graham Wallas, in his book The Art of Thought (excerpts reprinted in Rothenberg and Hausmann 1976), proposed that the creative process followed four distinct stages. These he called preparation, incubation, illumination and verification. He argued that the whole creative process must begin with preparation and end with verification, two aspects that have often been overlooked or discounted as crucial to any creative output. It should also be noted that there has been some discussion in the literature about these stages, particularly the existence or not of incubation (see, for example, Weisberg 1993; Bastick 1982) and the stages supposed temporal linearity (Csikszentmihalyi 1997).

13. The author has speculated that 'an explanation for this shift away from the perceptions of the fundamental elements of a song as lyric and melody, to a broader idea of the constituents of a song encompassing all of the aspects of a recorded work, can be seen in the corresponding demise of the sheet music industry and the rise of the recording industry' (McIntyre 2001, p. 106).

14. Ian Macdonald, in referring to Mark Lewisohn's earlier work, states that 'according to George Martin, McCartney wrote Yesterday while staying at the George V Hotel, Paris, in January 1964' (Macdonald 1994, p. 124). Lewisohn, however, wrote that 'George Martin remembers the genesis of the song. "I first heard 'Yesterday' when it was known as 'Scrambled Eggs'Paul's working title - at the George V Hotel in Paris in January 1964"' ' (Lewisohn 1988, p. 59). It's more likely that Martin, rather than being present at the writing of the song in its entirety, was privy to one of the many occurrences that McCartney undertook to attempt to work through and finalise the piece or, as he did with other members of the field, have Martin confirm the melody's originality.

15. Martin is also on record as saying, in seeming contradiction to these other accounts, that 'Paul said he wanted a one word title and was considering "Yesterday", except that he thought it was perhaps too corny. I persuaded him that it was all right' (quoted in Lewisohn 1992, p. 59).

16. Thanks must go to Danilo Jovanovitch for unearthing this detail from his collection of prewar sheet music. Similar gratitude also goes to Dietmar Lederwasch from Graphic Novel for 
access to his vast collection of memorabilia and literature.

17. Ian MacDonald has speculated that an organ version of 'Yesterday' was 'recent, if not precisely contemporary' with its studio recording on 14 June 1965 (MacDonald 1994, p. 125).

18. Bourdieu's theory of practice, according to David Swartz, 'may be seen as a probing reflection on one of the oldest problems in the Western intellectual tradition, namely, the relationship between the individual and society' (Swartz 1997, p. 96). Bourdieu himself stated that 'all of my thinking started from this point: how can behaviour be regulated without being the product of obedience to rules?' (Bourdieu, quoted in Swartz 1997, p. 95). As Randall Johnson explains, in his writings 'Bourdieu sought to develop a concept of agent free from the voluntarism and idealism of subjectivist accounts and a concept of social space free from the deterministic and mechanistic causality inherent in many objectivist approaches' (Johnson, in Bourdieu 1993, p. 4).

19. This quote from Martin tends to support Ian Macdonald's speculation that 'Martin is hardly likely to have let him risk his voice so flagrantly on another song earlier in the day', of also recording 'the shrieking choruses of " $\mathrm{I}$ 'm
Down"' (MacDonald 1994, p. 125). The fact that McCartney overdubbed his vocal three days after the initial vocal and guitar track was recorded is confirmed by Lewisohn (1992, p. 196).

20. This has been attempted in a musicological sense most famously by Wilfrid Mellers (1973) and also Ian Macdonald (1994) and more recently by Alan Pollack (2005) as part of his 'Notes On' series.

21. While it is problematic to delineate specific coherent periods attributable to the Beatles' work, with some disagreement occurring, for example, between Cook and Mercer (in Inglis 2000) and Heinonen and Eerola (2000), the author would agree with Heinonen and Eerola's periodisation whereby the early period includes works released on record from 1962-1965 ending with the album Help. In this case the middle period runs from 1965-1967 concluding with Magical Mystery Tour and the late period work runs from 1968-1970.

22. While McCartney collects approximately fifteen per cent of all monies earned through his songwriter's royalties (Miles 1997) he does not, despite his efforts, own the publishing rights to 'Yesterday' (Elson 1986).

\section{References}

Albert, R. 1992. Genius and Eminence (2nd edn) (Oxford, Pergamon Press)

Amabile, T., and Tighe, E. 1993. 'Questions of creativity', in Creativity: The Reality Club 4, ed. J. Brockman Jr (New York, Touchstone), pp. 7-27

Archer, M. 2003. Structure, Agency and the Internal Conversation (Cambridge, UK, Cambridge University Press)

Bailin, S. 1988. Achieving Extraordinary Ends: An Essay on Creativity (Boston, Kluwer Academic)

Bastick, T. 1982. Intuition: How We Think and Act (Chichester, UK, John Wiley \& Sons)

The Beatles. 2000. The Beatles: Anthology (San Francisco, Chronicle Books)

Becker, H. 1982. Art Worlds (Los Angeles, University of California Press)

Berger, A. 1995. The Essentials of Mass Communication Theory (Thousand Oaks, CA, Sage)

Boden, M. 1994. 'What is creativity', in Dimensions of Creativity, ed. M. Boden (Cambridge, MA, MIT Press), pp. 75-117

2004. The Creative Mind: Myths and Mechanisms (2nd edn) (London, Routledge)

Bourdieu, P. 1977. Outline of a Theory of Practice (Cambridge, Cambridge University Press) 1993. Field of Cultural Production, ed. R. Johnson (New York, Columbia University Press) 1996. The Rules of Art: Genesis and Structure of the Literary Field (Cambridge, Polity Press)

Cavallero, C., and Foulkes, D. (eds.) 1993. Dreaming as Cognition (New York, Harvester Wheatsheaf)

Coleman, R. 1995. McCartney: Yesterday and Today (London, Boxtree)

Csikszentmihalyi, M. 1988. 'Society, culture and person: a systems view of creativity', in The Nature of Creativity: Contemporary Psychological Perspectives, ed. R. Sternberg (New York, Cambridge University Press), pp. 325-39

1997. Creativity: Flow and the Psychology of Discovery and Invention (New York, Harper Collins)

1999. 'Implications of a systems perspective', in Handbook of Creativtiy, ed. R. Sternberg (Cambridge, UK, Cambridge University Press), pp. 314-15

Dawkins, R. 1986. The Blind Watchmaker (London, Longman Scientific \& Technical)

De Lisle, T. (ed.) [n.d.] Lives of the Great Songs (London, Penguin)

Elson, H. 1986. McCartney: Songwriter (London, W.H. Allen \& Co.)

Fitzgerald, J. 1996. Popular Songwriting 1963-1966: Stylistic Comparisons and Trends Within the U.S. Top Forty [unpublished thesis] (Lismore, Aust, Southern Cross University)

Fulpen, H. 1983. The Beatles: An Illustrated Diary (London, Plexus)

Gambaccini, P. 1976. Paul McCartney: In His Own Words (London, Omnibus Press)

Gardner, H. 1993. Creating Minds: An Anatomy of Creativity Seen Through the Lives of Freud, Einstein, Picasso, Stravinsky, Eliot, Graham and Gandhi (New York, Basic Books) 
Gelly, D. 1976. The Facts About a Pop Group (Sydney, Angus \& Robertson)

Giddens, A. 1979. Central Problems in Social Theory: Action, Structure and Contradiction in Social Analysis (London, MacMillan Press)

Hammond, I. 2002. 'Old sweet songs: in search of the source of "I Saw her Standing There" and "Yesterday" ', in Soundscapes - Journal on Media Culture, http:/ /www.icce.rug.nl/oger-bin/contents / print.cgi (accessed 28 April 2005)

Heinonen, Y., and Eerola, T. 2000. 'Songwriting, recording and style change: problems in the chronology and periodization of the musical style of the Beatles', in Soundscapes - Journal on Media Culture, 3, July, http:/ / www.icce.rug.nl/ soundscapes/VOLUME03/Songwriting_recording.html (accessed 12 April 2005)

Hendy, D. 2000. Radio in the Global Age (Cambridge, UK, Polity Press)

Heuger, M. 2005. 'Beabliography', in Soundscapes - Journal on Media Culture, http:/ /www.icce.rug.nl/ oger-bin/beab/db.cgi?db=default\&uid=\&view_records=1\&FirstLetter=M\&nh=1 (accessed 12 April 2005)

Howe, M. 1999. Genius Explained (Cambridge, UK, Cambridge University Press)

Inglis, I. (ed.) 2000. The Beatles, Popular Music and Society: A Thousand Voices (London, MacMillan Press)

Lewisohn, M. 1988. The Complete Beatles Recording Sessions: The Official Story of the Abbey Road Years (London, Hamlyn)

1992. The Complete Beatles Chronicle (London, Pyramid Books)

MacDonald, I. 1994. Revolution in the Head. The Beatles' Records and the Sixties (London, Pimlico)

Mandler, G. 1995. 'Origins and consequences of novelty', in The Creative Cognition Approach, ed. S. Smith, T. Ward and R. Finke (Cambridge, MA, Bradford Books), pp. 9-25

Martin, G. 1979. All You Need is Ears (New York, St. Martin's Press) 1994. Summer of Love: The Making of Sot Pepper (London, MacMillan Press)

McCarly, R., and Hobson, J. 1981. 'REM sleep dreams and the activation-synthesis hypothesis', American Journal of Psychiatry, 138, pp. 904-12

McIntyre, P. 2001. 'The domain of songwriters: towards defining the term "song" ', Perfect Beat, V5, N3, pp. 100-11

Mellers, W. 1973. Twilight of the Gods. The Beatles in Retrospect (London, Faber \& Faber)

Miles, B. 1997. Paul McCartney: Many Years From Now (London, Secker \& Warburg)

Negus, K., and Pickering, M. 2002. 'Creativity and musical experience', in Popular Music Studies, ed. D. Hesmondhalgh and K. Negus (London, Arnold).

2004. Communication, Creativity and Cultural Value, (London, Sage)

Pedler, D. 2001A. 'The songwriting roots of the Beatles', in Total Guitar, November, ed. S. Rowley (London, Future Publishing)

2001в. The Songwriting Secrets of the Beatles (London, Omnibus Press)

Perelman, B. 1994. The Trouble with Genius (Berkeley, University of California Press)

Petrie, D. 1991. Creativity and Constraint in the British Film Industry (London, MacMillan Press)

Pollack, A. 2005. 'Notes on Yesterday', in Alan W. Pollacks's 'Notes On' Series, http:/ / www.recmusicbeatles. com/public/files/awp/awp.html (accessed 28 April 2005)

Rothenberg, A., and Hausman, C. (eds.) 1976. The Creativity Question (Durham, NC, Duke University Press)

Salewicz, C. 1986. McCartney: The Biography (London, Futura)

Schon, D. 1983. The Reflective Practitioner: How Professionals Think in Action (New York, Basic Books)

Schultheiss, T. 1980. The Beatles: A Day in the Life (The Day-by-Day Diaries 1960-1970) (London, Omnibus Press)

Shuker, R. 1994. Understanding Popular Music (London, Routledge)

Snow, M. 1995. 'God in heaven what was I on', MOJO, November (London, EMAP Metro)

Stein, M. 1953. 'Creativity and culture', The Journal of Psychology, 36, pp. 311-22

Sternberg, R. (ed.) 1988. The Nature of Creativity: Contemporary Psychological Perspectives (New York, Cambridge University Press)

1995. In Search of the Human Mind (New York, Harcourt Brace)

(ed.) 1999. Handbook of Creativity (Cambridge, UK, Cambridge University Press)

Stillinger, J. 1991. Multiple Authorship and the Myth of Solitary Genius (New York, Oxford University Press)

Sullivan, H. 1955. Conceptions of Modern Psychiatry (London, Tavistock)

Swartz, D. 1997. Culture and Power: The Sociology of Pierre Bourdieu (Chicago, University of Chicago Press)

Thussu, D. 2002. International Communication: Continuity and Change (London, Arnold)

Toynbee, J. 2000. Making Popular Music: Musicians, Creativity and Institutions (London, Arnold)

Van Fulpen, H. 1983. The Beatles: An Illustrated Diary (London, Plexus)

Watson, P. 2001. A Terrible Beauty: The People and Ideas that Shaped the Modern Mind: A History (London, Phoenix)

Weisberg, R. 1993. Creativity: Beyond the Myth of Genius (New York, W.H. Freeman \& Co.)

1999. 'Creativity and knowledge: a challenge to theories', in Handbook of Creativity, ed. R. Sternberg (Cambridge, UK, Cambridge University Press), pp. 226-50

Weiten, W. 1998. Psychology: Themes and Variations (4th edn) (Pacific Grove, CA, Brooks Cole) 
Williams, R. 1961. The Long Revolution (London, Chatto \& Windus)

Wolman, B. (ed.) 1979. Handbook of Dreams: Research, Theories and Applications (New York, Van Nostrand Reinhold)

Yin, R. 1989. Case Study Research: Design and Methods (Newbury Park, CA, Sage) 